\title{
PACAP and NAP: Effect of Two Functionally Related Peptides in Diabetic Retinopathy
}

\author{
Agata Grazia D'Amico ${ }^{1} \cdot$ Grazia Maugeri $^{2} \cdot$ Giuseppe Musumeci $^{2} \cdot$ Dora Reglodi $^{3} \cdot$ Velia D'Agata $^{2}$ (I)
}

Received: 27 October 2020 / Accepted: 30 November 2020

( $)$ The Author(s), under exclusive licence to Springer Science+Business Media, LLC part of Springer Nature 2021

\begin{abstract}
Pituitary adenylate cyclase-activating polypeptide (PACAP) is a peptide involved in physio-pathological processes of the eye. It exerts multiple effects directly through activation of its related receptors and indirectly through increases in the synthesis of activity-dependent neuroprotective protein (ADNP). To study the role of ADNP and protect against ADNP deficiencies, a small peptide called NAP was synthetized. It includes an eight amino acid active site sequence of ADNP. In this review, we summarize the knowledge regarding the neuroprotective function played by PACAP and NAP in retinal tissue and provide an overview of the correlation between PACAP and ADNP in the context of diabetic retinopathy.
\end{abstract}

Keywords Diabetic retinopathy $\cdot$ PACAP $\cdot$ ADNP $\cdot$ NAP $\cdot$ Hyperglycemia

\section{Introduction}

Pituitary adenylate cyclase-activating polypeptide (PACAP) is a neuropeptide encoded by the ADCYAP1 gene that belongs to the vasoactive intestinal polypeptide (VIP)secretin-glucagon peptide superfamily (Harmar et al. 1998; Arimura and Shioda 1995). This neuropeptide was first isolated from ovine hypothalamus by Miyata and coworkers in 1989. PACAP and its related receptors are expressed in the central nervous system (CNS) and in most peripheral organs (Ghatei et al. 1993; Arimura and Shioda 1995; Vaudry 2009; Moody et al. 2020; Girard et al. 2020; Toth et al. 2020). This peptide exists in two isoforms: PACAP38, which includes 38 aminoacids, and PACAP27, which is PACAP-38 truncated in C-terminal form and includes 27 aminoacids. It shows a high

Agata Grazia D’Amico and Grazia Maugeri equally contributed.

Velia D'Agata

vdagata@unict.it

1 Department of Drug Sciences, University of Catania, Catania, Italy

2 Department of Biomedical and Biotechnological Sciences, Section of Anatomy, Histology and Movement Sciences, University of Catania, Catania, Italy

3 Department of Anatomy, MTA-PTE PACAP Research Group, University of Pécs Medical School, Pécs, Hungary sequence homology with vasoactive intestinal polypeptide (VIP) (Miyata et al. 1989; 1990; Segre and Goldring 1993).

PACAP is a pleiotropic peptide, as it is involved in a wide array of physiological processes such as neuromodulation of immune response, neuroprotection, and stimulation of cell proliferation. It also plays a protective effect in several pathologies affecting the CNS and eye, including retinopathies (Canonico et al. 1996; Arimura et al., 1998; Vaudry et al. 2003; 2009; Giunta et al. 2010; Nackamachi et al. 2011, 2012, 2016; Atlasz et al. 2010a and 2010b; Varga et al. 2011; Scuderi et al. 2013; Castorina et al. 2014; Maugeri et al. 2018; 2019a; Kovacs et al. 2020; Martínez-Rojas et al. 2020; Józsa et al. 2001).

PACAP carries out its functions in tissue-specific manner by binding to different $\mathrm{G}$ protein-coupled receptors including PAC1 (PAC1-R), VPAC-1, and VPAC-2 receptors (VPAC1-R and VPAC2-R) (Vaudry 2009). The PAC1$\mathrm{R}$ was first isolated in rat pancreatic acinar carcinoma cell line, whereas VPAC receptors were isolated initially in rat lung and olfactory bulb (Hosoya et al. 1993; Morrow et al. 1993; Svoboda et al. 1993; Lutz et al. 1993; Laburthe et al. 2002). The cDNA of the rat VPAC-1 receptor encodes for a protein of 459-amino acid and shows a sequence identity of the 50\% to the rat PAC1-R (Pisegna and Wank 1993). PAC1-R receptor binds to PACAP with higher affinity than VPAC1 and 2 receptors (Vaudry 2009; Harmar et al. 2012). PAC1-R exists in diverse splice variants (Null, Hip, Hop1, Hop2, Hiphop1, Hiphop2, short and very short isoforms) 
that differ at the N-terminal domain and/or in the third intracellular loop (Blechman 2013). These isoforms can activate two different signaling cascades: the adenylate cyclase (AC) pathway activating cAMP and phospholipase C (PLC) pathway stimulating protein kinase $\mathrm{C}$ (PKC) formation (Lack et al. 2015). By binding to VPAC-1 and VPAC-2 receptors, PACAP induces the activation of $\mathrm{AC}$ as well as some other signaling cascades independently by cAMP (SomogyvariVigh and Reglodi, 2004; Ohtaki et al., 2008; Shioda et al. 2006; Waschek et al. 2002). Therefore, multiple effects of PACAP depend on the concentration of the peptide and receptor splice variant expressed in the specific tissue and cell (Ashur-Fabian et al. 1997; Pilzer et al. 2006).

PACAP's activity on cell proliferation and differentiation in the CNS is also carried out through the stimulation of an intracellular astrocyte-derived neurotrophic factor known as activity-dependent protein (ADNP) (Bassan et al. 1999; Zamostiano et al. 2001). ADNP is a neuroprotective protein of $123.56 \mathrm{kDa}$ largely distributed throughout the body, including the CNS, where it is involved in brain development and cognition (Gozes 1999; Gozes et al. 2002; Pinhasov et al. 2003). This protein is an essential factor during embryogenesis, as it has been demonstrated that ADNP-knockout mice have impairment in neural tube closure (Pinhasov et al. 2003). It was demonstrated that PACAP increases ADNP level in young astrocytes and in co-cultures of neurons and glial cells (Zusev et al. 2004; Li et al. 2005), suggesting that some intracellular activity of PACAP could be mediated by ADNP-induction. This evidence was corroborated by other studies demonstrating that ADNP is a mediator of some PACAP neuroprotective activity. It was proven that PACAP-38 induced ADNP expression in a bimodal manner depending on its concentration. More specifically, subpicomolar concentration of PACAP stimulates ADNP release via PAC1-R, whereas nanomolar concentration of peptide induces ADNP expression mediated by VPAC1-R (Nakamachi et al., 2006) . Furthermore, Nakamachi et al. (2008) revealed that ADNP and PAC1-R co-localized in different areas of mouse brain, suggesting that ADNP expression in neurons and astrocytes is regulated by PACAP. Interestingly, in an in vivo mouse model of ADNP deficiency, PACAP provided protection (Sragovich et al. 2019).

To identify the ADNP neuroprotective active site, small peptides were synthesized and a small peptide known as NAP was discovered. This small active element exerts protective activity at femtomolar concentration (Bassan et al. 1999; Pinhasov et al. 2003). The protective action of NAP was demonstrated in many in vitro and in vivo studies; it prevents apoptotic cell death in neurons exposed to different kinds of stress such as glucose deprivation and $\beta$-amyloid or tetrodotoxin treatment, and in a rat model of cerebral ischemia and severe head injury (Bassan et al. 1999; Leker et al. 2002; Beni-Adani et al. 2001; Zaltzman et al. 2005; Zemlyak et al. 2007; Jehle et al. 2008; Gozes et al. 2008; Belokopytov et al. 2011). Noteworthy, the chemical structure of this small fragment peptide allows it to penetrate into cell membrane and by binding to microtubules it protects astrocytes and neurons (Divinski et al. 2004; Oz et al. 2012; 2014; Ivashko-Pachima et al. 2017; 2018; 2019a and 2019b; 2020; Gozes et al. 2015; 2018; 2019; Grigg et al. 2020). Furthermore, it has been demonstrated that NAP provides significant neuroprotection also in a diabetes rat model (Idan-Feldman et al. 2011) and it has been also showed that NAP regulates PAC1 expression (Kapitansky et al. 2020).

\section{Retinal Expression of PACAP and ADNP}

To date, various studies have provided detailed descriptions of the retinal distribution of PACAP and related receptors in different mammalian species and described retinoprotective functions in response to different insults (Onali et al. 1994; Wang et al. 1995; D'Agata and Cavallaro 1998; Cavallaro et al 1996; Silveira et al. 2002; Borba et al. 2005). In situ hybridization and immunohistochemical studies have revealed that PAC1-R is strongly expressed in the ganglion cell layer (GCL), inner nuclear layer (INL), and nerve fiber layer (NFL), while a weak expression was found in the inner plexiform layer (IPL), outer plexiform layer (OPL), outer nuclear layer (ONL), and photoreceptor layer (Seki et al. 1997, 1998, 2000a, 2000b). Furthermore, other papers have described the retinal distribution of PAC1-R splice variants, Null, Hip, Hop1, Hop2, and Hiphop1, as well as VPAC-1 and VPAC-2 receptors (Lakk et al. 2012; Zhang et al. 2005). The presence of PACAP has been found in mammalian, teleost, turtle, and chicken retina using immunohistochemistry (Reglodi et al. 2001). The peptide expression was identified in rat retinohypotalamic tract and amacrine and horizontal cells, the GCL, and the NFL, whereas it was absent in photoreceptor layer and in retinal pigmented epithelium (Seki et al. 1997; 1998; Hannibal 1997 and 2002). At the ultrastructural level, PACAP was detected in the plasma membranes, rough endoplasmic reticulum, and cytoplasmic matrix in retinal INL neurons (Seki et al. 1997; 2000a, b).

In our previous work, we have demonstrated that a significant reduction of mRNA expression of PACAP and its related receptors occurs in diabetic rat retinas (Giunta et al. 2012). Furthermore, we have also proven that ADNP mRNA retinal expression is significantly downregulated in diabetic rats compared with control animals (Scuderi et al. 2014). This confirms that ADNP expression is affected by hyperglycemic condition similarly to PACAP, suggesting that hyperglycemic insult on retinal functions is at least in part linked to impairment of endogenous PACAP and ADNP levels. 


\section{PACAP and NAP Retinal Protection}

The protective effect of PACAP has been largely demonstrated in different in vivo and in vitro models of retinopathy, including UVA-induced retinal damage (Atlasz et al. 2011), retinal ischemia (Atlasz et al. 2007; 2010a, b; Seki et al. 2011; Ye et al. 2019), glutamate toxicity (Atlasz et al. 2008; 2009), and diabetic retinopathy (Szabadfi et al. 2016). Moreover, its activity has been also demonstrated during retinal development, as it interferes with retinal progenitor cells proliferation (Njaine et al. 2010). It has also been suggested that PACAP counteracts retinal aging process since PACAP knock-out mice showed an early degeneration of the retina (Kovács-Valasek et al. 2017).

Numerous studies have demonstrated that PACAP exerts its retinoprotective effects in a dose-dependent manner. In fact, this peptide modulates apoptotic cell death occurring after retinal monosodium glutamate lesion (Racz et al. 2006a and 2006b) by inducing a cAMP/PKA signaling cascade at micromolar or nanomolar concentration (Silveira et al. 2002; Racz et al. 2007) or PLC pathway at a picomolar dose (Lakk et al. 2015). The PACAP administration counteracts retinal hypoperfusion after bilateral common carotid occlusion (BCCAO) through modulation of inflammatory cytokines, induction of MAPKs phosphorylation, and concomitant reduction of apoptotic related genes, including JNK and p38 (Szabo et al. 2012). Furthermore, it has been demonstrated that PACAP crosses the ocular barriers and is able to exert neuroprotective effect even given in eye drops in rat chronic retinal ischemia (Werling et al. 2016, 2017). The protective role is also associated to functional improvement, as demonstrated by measuring electrical activity after retinal hypoxia (Danyadi et al. 2014). In this context, by using the PAC1-selective agonist maxadilan, it has been suggested that PACAP's effect is mediated through PAC1 receptor activation (Vaczy et al. 2016). The protective role of PACAP was also demonstrated in a rodent model of retinopathy of prematurity (Kvarik et al. 2016). In this model, the intravitreal injections of PACAP have significantly reduced the oxygen-induced damage in the retinal tissue by increasing vascularized area and counteracting the expression of proinflammatory cytokines. In accord to these evidences, studies conducted by using in vitro models of oxidative stress demonstrated that PACAP reduces expression of inflammatory cytokines in human retinal pigment epithelial cells and also counteracts cellular apoptotic death interfering with the balance between pro- and anti-apoptotic genes (Zhang et al. 2005; Mester et al. 2011; Fabian et al 2012). More recently, Fabian and coworkers (2019) have demonstrated the efficacy of PACAP in counteracting morphological changes occurring in human retinal pigmented epithelium cells (ARPE-19) exposed to hyper-osmosis and oxidative stress. They also demonstrated that PACAP inhibits VEGF release in these cells. Furthermore, PACAP counteracts glutamate-induced excitotoxicity by reducing glutamate, decreasing proinflammatory factors, and concomitantly normalizing glutathione levels that play an important role as free radical scavengers (D'Alessandro et al. 2014).

Although PACAP exerts numerous effects acting through the signaling pathways mentioned above, its activity is also mediated by induction of neuroprotective molecules from glial cells, including microglia and macrophages, as well as Müller glial cells (Nakatani et al. 2006; Wada et al. 2013; Werling et al. 2016). In a rodent model of ischemia, it has been demonstrated that PACAP counteracts the morphological retinal changes by reducing GFAP expression occurring in Müller cells (Atlasz 2010b), representing the retinal cells activated first following an insult. Thus, the modulatory effect of PACAP on glial cells could underlie to its neuroprotective action. The glial cells in the retinal are involved in maintaining the correct retinal microenvironment in neurons and vessels. These cells are primarily responsible for regulation of retinal ions, levels of glutamate, and counteracting retinal impairments due to stress caused by free radicals or hypoxia, by modulating glutathione synthesis. Any retinal damage leads to microenvironmental alterations with consequent hyper-activation of Müller cells. This event leads to increased expression of glial fibrillary acidic protein (GFAP) in Müller cells, which in turn may be accompanied by hypertrophy and cellular proliferation in damaged tissue. Among insults able to induce retinal alterations, hyperglycemia triggers enhanced expression of GFAP in Müller cells in the early phase of diabetes in both humans and animal experimental models (Gabriel et al. 2013, 2019). Therefore, it was suggested that activation of Müller glial cells could represent the first scenario in this pathology. In the context of increased glucose levels, these glial cells activate ion-regulatory machinery and induce the release of different molecules including vascular endothelial growth factor (VEGF), and inflammatory cytokines such as interleukins or tumor necrosis factor, which are responsible for triggering the degeneration process. In this context, it has been demonstrated that PACAP is able to ameliorate pathological Müller glial induction during diabetic retinopathy (Szabadfi et al. 2014, 2016).

Among glial mediators of PACAP' actions, the astrocytes-released neuroprotective protein, ADNP, has also been suggested (Gozes et al. 2003). The smallest active element of this protein is an octapeptide named NAP that has shown to exert beneficial effects in different retinal pathologies. It protects neuroretinal cells from hypoxic damage because it induces neurite growth of retinal ganglion cell (RGC) in retinal explant of rat pups and counteracts RGC injuries 
following optic nerve crush and retinal ischemia (Jehle et al. 2008). Furthermore, Zheng et al. (2010) have demonstrated that NAP transfection into Müller cells protects them and surrounding retinal neurons from hypoxia. Intravitreal administration of NAP is also efficacious in counteracting laser-induced retinal damage (Lagrèze et al. 2005; Belokopytov et al. 2011).

\section{Effect of PACAP and NAP in Diabetic Retinopathy}

Among ocular pathological conditions, diabetic retinopathy (DR) is the most common disease affecting patients with Type 1 or Type 2 diabetes (Yau et al. 2012; Gabriel et al. 2019). It represents a microvascular complication of diabetes leading to blindness. The retinal impairments during diabetic retinopathy can be ascribable to metabolic changes caused by hyperglycemia leading to microvascular alteration, retinal hypoxia, inflammation, impairments of retinal architecture, and consequent general tissue dysfunction. The micro environmental changes that followed DR lead to thinning of retinal layers, loss of GCL, a decreased number of amacrine cells, and rods and cones (Holopigian et al. 1997; Gastinger et al. 2006). It also leads to activation of Müller cells and astrocytes at the onset of diabetes (Zeng et al. 2000, 2008; Puro et al. 2002). It was also demonstrated that rat retinal Müller cells are impaired by hypoxic insult causing neuroretinal dysfunction (Bringmann et al. 2001; Puro 2002). This scenario is additionally characterized by apoptosis of neuronal cells, synapse loss among retinal layers, and significant loss of ganglion cells that occurs at the early stage of diabetes (Szabadfi et al. 2016).

It has been proven that alterations characterizing DR progression are attenuated or counteracted by treatment with peptides, including PACAP and NAP. As summarized in Table 1, the neuroprotective effect of these peptides has been widely demonstrated in several studies. For instance, the intravitreal injection of PACAP has been shown to play a significant ameliorative effect against retinal degenerations in streptozotocin-induced diabetic rats. More specifically, PACAP preserves cone photoreceptors damages, counteracts the reduction of ganglion and dopaminergic amacrine cells (Szabadfi et al. 2012), and it is able to rescue neurons from apoptotic death (Szabadfi et al. 2014).

In line with this evidence, our research group has demonstrated that PACAP plays a neuroprotective activity in the retina during the early phase of DR. In fact, PACAP and its related receptors are downregulated after three weeks of hyperglycemia, suggesting their involvement in retinal dysfunction during diabetes. In this model, a single injection of PACAP provided neuroprotection in the diabetic retina by inducing modulation of apoptotic genes expression such as p53 and Bcl2 levels (Giunta et al. 2012).

To deepen our knowledge on the molecular mechanisms underlying PACAP's effect in this pathology, we investigated whether its activity was directly linked ADNP induction in retinal tissue. We tested the effect of ADNP's smallest active element, NAP, in a model in vivo of rat DR. We demonstrated that both NAP and PACAP are able to improve retinal morphology, counteract its thinning, and reduce loss of GCL at early phase of hyperglycemia (D'Amico et al. 2017a). We have also shown that a single dose of NAP was able to decrease the rate of apoptotic cell death by activating the MAPK/ERK pathway in diabetic retina (Scuderi et al. 2014). Furthermore, both NAP and PACAP interfere with hypoxia signaling pathway occurring 3 weeks from the beginning of hyperglycemia. In particular, both peptides modulate the expression of some hypoxic inducible factors (HIFs). The latter are heterodimeric transcription factors representing the first biological response to cellular hypoxia. Among these, HIF- $1 \alpha$ and HIF- $2 \alpha$ under hypoxia elude the proteasome degradation system, translocate into the nucleus and activate many target genes. These genes include VEGF, the main

Table 1 Summary of knowledge regard PACAP and NAP effect in diabetic retinopathy

\begin{tabular}{ll}
\hline Key findings & Reference \\
\hline $\begin{array}{l}\text { Treatment of PACAP prevents cone photoreceptor damage and reduction of ganglion and dopaminergic amacrine } \\
\text { cells }\end{array}$ & Szabadfi et al. (2012) \\
$\begin{array}{l}\text { PACAP provides neuroprotection in diabetic retina by inducing modulation of apoptotic genes, reducing p53 and } \\
\text { increasing Bcl2 levels }\end{array}$ & Giunta et al. (2012) \\
PACAP counteracts neural apoptotic death, by inducing expression of antiapoptotic p-Akt, p-ERK1-2, PKC, and Bcl- & Szabadfi et al. (2014) \\
2 & \\
NAP treatment reduces apoptotic retinal cell death and improves cell survival by inducing MAPK/ERK & Scuderi et al. (2014) \\
PACAP interferes with hypoxia inducible factors (HIFs) & D'Amico et al. (2015) \\
PACAP treatment saves ribbon synapses and pigment epithelial cell morphology & Szabadfi et al. (2016) \\
PACAP treatment reduces expression levels of IL-1 $\beta$, VEGF, and VEGFRs & D'Amico et al. (2017a) \\
NAP treatment modulates Hypoxia signaling cascade by reducing expression of HIF-1 $\alpha$, HIF-2 $\alpha$, and VEGF & D'Amico (2017b) \\
PACAP treatment induces EGFR phosphorylation via PKA-signaling cascade activation & Maugeri et al. (2019a, b)
\end{tabular}


factor responsible to microvasculature system dysfunction. In diabetic rat retinas, HIF- $1 \alpha$ and HIF- $2 \alpha$ are aberrantly expressed since they are upregulated in different retinal layers including INL and ONL. PACAP and NAP administration significantly downregulates HIF- $1 \alpha$ and HIF- $2 \alpha$ expression and, at the same time, enhances HIF-3 $\alpha$ levels in diabetic retina (D'Amico et al. 2015, 2017b; Maugeri et al. 2017a). This finding was relevant because HIF-3 $\alpha$ is well-known as a negative regulator of the other two hypoxic inducible factors and inhibits their activity. Noteworthy, PACAP and NAP also significantly reduced VEGF levels in diabetes-affected retina and abrogated its expression in the GCL, including ganglionic cells, the axons of which form the optic nerve (D'Amico et al. 2017a and b). Therefore, these two peptides represent two factors able to act as upstream regulators of VEGF expression. This data is in agreement with the ameliorative effect played by PACAP in counteract vascular dysfunction hyperglycemia-induced (Solymar et al. 2018).

This is relevant evidence because anti-VEGF-therapy represents an elective tool in DR treatment, although it is efficacious only in $50 \%$ of treated-patients. The identification of molecules able to modulate the expression of this angiogenic growth factor could represent a new therapeutic strategy to prevent angiogenesis in non-responders. In our studies, we have demonstrated that PACAP and NAP are

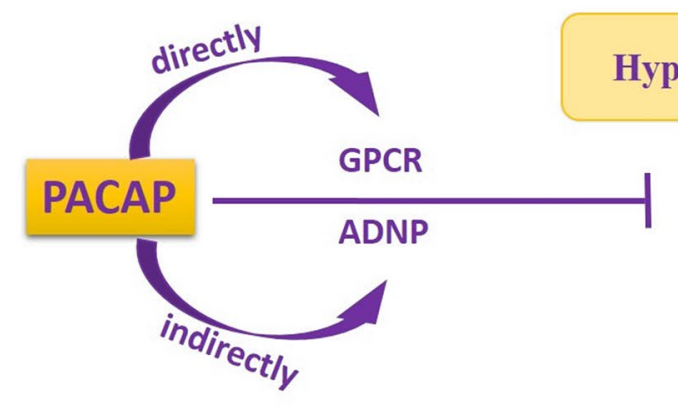

\section{Hyperglycemia}
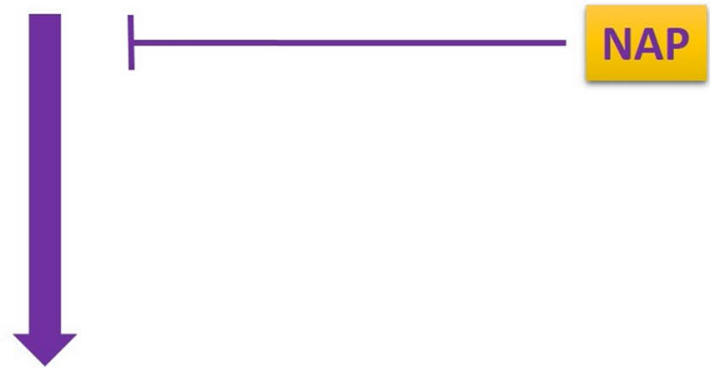

In vivo model of $\mathrm{DR}$

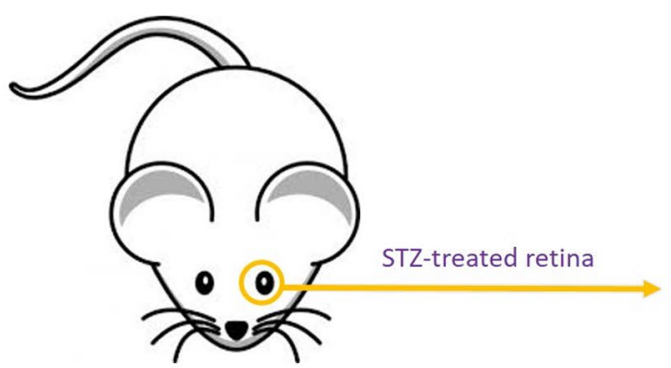

Fig. 1 Graphical representation of PACAP and NAP effect in hyperglycemic retina. Hyperglycemia induces retinal damage during diabetes, by promoting tissue inflammation, hypoxia, and apoptosis. This event leads to alterations of retinal architecture and consequent general dysfunction mirroring loss of ganglion cell layer (GCL) and thinning of inner plexiform layer (IPL), inner nuclear layer (INL), outer plexiform layer (OPL), and outer nuclear layer (ONL). PACAP exert its neuroprotective action on diabetic retina directly by binding to its related receptors or indirectly by inducing ADNP secretion. Exogenous administration of NAP, the smallest active element of this neurotrophic protein, and PACAP counteracts the hyperglycemia-induced metabolic changes 
able to interfere with the HIF-VEGF signaling cascade at the early stage of hyperglycemia.

As mentioned above, hyperglycemia/hypoxia also stimulates release of inflammatory cytokines. Among these, IL-1 $\beta$ was described as a mediator of retinal tissue damage at early stages of the disease. In line with this evidence, we demonstrated that this cytokine and its related receptors, IL-1R1 more than IL-1R2, were upregulated in diabetic rat retinas. During hyperglycemia, IL-1 $\beta$ and IL-1R1 are overexpressed in the photoreceptor layer and in the ONL, highlighting the induction of inflammatory process in specific retinal regions as well as their involvement in blood retinal barrier breakdown (BRB) during DR progression (Scuderi et al. 2015). For the first time, we have demonstrated that PACAP and NAP counteract this inflammatory event, by downregulating IL-1 $\beta$ and IL-1R 1 aberrant expression, and maintaining BRB integrity (D'Amico et al. 2018, 2019; Maugeri et al. 2017b; Fabian et al. 2019). The maintenance of BRB integrity is fundamental for visual function. The impairment of this structure in macular region leads to diabetic macular edema (DME), a serious complication leading to vision loss. $\mathrm{BRB}$ is constituted by an inner compartment, known as inner $\mathrm{BRB}$, that is represented by vascular endothelium and an outer compartment, known as outer BRB, characterized by retinal pigmented epithelium (RPE) (Simó et al. 2010). These cells play a protective role in survival of photoreceptor exposed to different insults. Therefore, the identification of molecules able to preserve RPE survival represents a further therapeutic approach in the retinal diseases.

Our research group has demonstrated the ameliorative effect played by PACAP and NAP in maintenance of outer BRB integrity. More specifically, we showed that PACAP and NAP preserve barrier integrity by reducing hyper-permeability of pigment epithelium exposed to various insults accounting for diabetic macular edema (i.e., high glucose and interleukin $1 \beta$ ). In these cells, PACAP and NAP preserve retinal pigment epithelial cell monolayer by inhibiting HIFs-VEGF signaling cascade and reducing pro-inflammatory pathway. Recently, we have demonstrated that PACAP exert its activity also through induction of EGFR phosphorylation in DR. (Maugeri et al. 2019b).

Overall, these evidences suggest that the neuroprotective effect of PACAP is mediated, at least in part, by ADNP induction in the diabetic retina, summarized in Fig. 1.

\section{Conclusion}

In conclusion, PACAP and NAP play a key role in retinal physiopathology; however, while PACAP's half-life is a minute or shorter, NAP's half-life is relatively long for a peptide, half an hour. NAP has previously been used in clinical trials showing safety and tolerability as well as efficacy increasing cognitive functions and protecting activities of daily living in mild cognitive impairment patients and schizophrenia patients, respectively (Gozes 2020). Overall, the evidences reported suggest that PACAP and NAP could be considered good candidates for therapeutic approach to DR.

Authors' contributions A.G.D and G.M.: writing original draft preparation, V.D and D.R: writing - review and editing, G.M: visualization, V.D: supervision, D.R: funding acquisition. All authors have read and agreed to the published version of the manuscript.

Funding National Research, Development and Innovation Fund NKFIH135457, 129190, National Brain Research Program NAP20171.2.1-NKP-2017-00002; MTA-TKI-14016; GINOP-2.3.2-15-201600050 "PEPSYS"; FIKP Program.

\section{Compliance with Ethical Standards}

Competing Interests The authors declare that they have no conflict of interest.

Consent for Publication The authors agree to publication.

\section{References}

Arimura A (1998) Perspectives on pituitary adenylate cyclase activating polypeptide (PACAP) in the neuroendocrine, endocrine, and nervous systems. Jpn J Physiol 48:301-331. https://doi. org/10.2170/jjphysiol.48.301

Arimura A, Shioda S (1995) Pituitary adenylate cyclase activating polypeptide (PACAP) and its receptors: neuroendocrine and endocrine interaction. Front Neuroendocrinol 16:53-88. https:// doi.org/10.1006/frne.1995.1003

Ashur-Fabian O, Giladi E, Brenneman DE, Gozes I (1997) Identification of VIP/PACAP receptors on rat astrocytes using antisense oligodeoxynucleotides. J Mol Neurosci 9(3):211-222. https:// doi.org/10.1007/BF02800503

Atlasz T, Babai N, Kiss P, Reglodi D, Tamás A, Szabadfi K, Tóth G, Hegyi O, Lubics A, Gábriel R (2007) Pituitary adenylate cyclase activating polypeptide is protective in bilateral carotid occlusion-induced retinal lesion in rats. Gen Comp Endocrinol 153(1-3):108-114. https://doi.org/10.1016/j.ygcen.2006.12.022

Atlasz T, Szabadfi K, Kiss P, Babai N, Koszegi Z, Tamas A, Reglodi D, Gabriel R (2008) PACAP-mediated neuroprotection of neurochemically identified cell types in MSG-induced retinal degeneration. J Mol Neurosci 36:97-104. https://doi. org/10.1007/s12031-008-9059-5

Atlasz T, Szabadfi K, Kiss P, Marton Z, Griecs M, Hamza L, Gaal V, Biro Z, Tamas A, Hild G, Nyitrai M, Toth G, Reglodi D, Gabriel R (2011) Effects of PACAP in UV-A radiation-induced retinal degeneration models in rats. J Mol Neurosci 43:51-57. https://doi.org/10.1007/s12031-010-9392-3

Atlasz T, Szabadfi K, Kiss P, Racz B, Gallyas F, Tamas A, Gaal V, Marton Z, Gabriel R, Reglodi D (2010) Pituitary adenylate cyclase activating polypeptide in the retina: focus on the retinoprotective effects. Ann N Y Acad Sci 1200:128-139

Atlasz T, Szabadfi K, Kiss P, Tamas A, Toth G, Reglodi D, Gabriel R (2010) Evaluation of the protective effects of PACAP with 
cell-specific markers in ischemia-induced retinal degeneration. Brain Res Bull 81(4-5):497-504

Atlasz T, Szabadfi K, Reglodi D, Kiss P, Tamas A, Tóth G, Molnár A, Szabó K, Gábriel R (2009) Effects of pituitary adenylate cyclase activating polypeptide and its fragments on retinal degeneration induced by neonatal monosodium glutamate treatment. Ann N Y Acad Sci 1163:348-352. https://doi. org/10.1111/j.1749-6632.2008.03650.x

Bassan M, Zamostiano R, Davidson A, Pinhasov A, Giladi E, Perl O, Bassan H, Blat C, Gibney G, Glazner G, Brenneman DE, Gozes I (1999) Complete sequence of a novel protein containing a femtomolar-activity-dependent neuroprotective peptide. J Neurochem 72:1283-1293. https://doi.org/10. 1046/j.1471-4159.1999.0721283.x

Belokopytov M, Shulman S, Dubinsky G, Gozes I, Belkin M, Rozner M (2011) Ameliorative effect of NAP on laser-induced retinal damage. Ameliorative effect of NAP on laser-induced retinal damage. Acta Ophthalmol 89(2):e126-31. https://doi.org/10. 1111/j.1755-3768.2010.02041.x

Beni-Adani L, Gozes I, Cohen Y, Assaf Y, Steingart RA, Brenneman DE, Eizenberg O, Trembolver V, Shohami E (2001) A peptide derived from activity-dependent neuroprotective protein (ADNP) ameliorates injury response in closed head injury in mice. J Pharmacol Exp Ther 296(1):57-63

Blechman J, Levkowitz G (2013) Alternative splicing of the pituitary adenylate cyclase-activating polypeptide receptor PAC1: mechanisms of fine tuning of brain activity. Front Endocrinol (Lausanne) 4:55. https://doi.org/10.3389/fendo.2013.00055

Borba J, Pereira Henze I, Silveira M, Cussa Kubrusly R, Gardino P, Fialho de Mello MC, Hokoç JN, Garcia de Mello F (2005) Pituitary adenylate cyclase-activating polypeptide (PACAP) can act as determinant of the tyrosine hydroxylase phenotype of dopaminergic cells during retina development. Brain Res Dev Brain Res 156(2):193-201. https://doi.org/10.1016/j. devbrainres.2005.02.016

Bringmann A, Reichenbach A (2001) Role of Muller cells in retinal degenerations. Front Biosci 6:E72-92

Canonico PL, Copani A, D’Agata V, Musco S, Petralia S, Travali S, Stivala F, Cavallaro S (1996) Activation of pituitary adenylate cyclase-activating polypeptide receptors prevents apoptotic cell death in cultured cerebellar granule cells. Ann N Y Acad Sci 805:470-472. https://doi.org/10.1111/j.1749-6632.1996. tb17505.x

Castorina A, Scuderi S, D'Amico AG, Drago F, D'Agata V (2014) PACAP and VIP increase the expression of myelin-related proteins in rat schwannoma cells: involvement of PAC1/VPAC2 receptor-mediated activation of PI3K/Akt signaling pathways. Exp Cell Res. 322(1):108-21. https://doi.org/10.1016/j. yexcr.2013.11.003

Cavallaro S, D’Agata V, Drago F, Musco S, Nuciforo G, Ricciardolo F, Tracali S, Sticala F, Arimura A, Canonico PL (1996) Ocular expression of type-1 pituitary adenylate cyclase-activating polypeptide (PACAP) receptors. Ann N Y Acad Sci 26(805):555-557. https://doi.org/10.1111/j.1749-6632.1996. tb17518.x (PMID: 8993438)

D'Alessandro A, Cervia D, Catalani E, Gevi F, Zolla L, Casini G (2014) Protective effects of the neuropeptides PACAP, substance $\mathrm{P}$ and the somatostatin analogue octreotide in retinal ischemia: a metabolomic analysis. Mol Biosyst 10(6):12901304. https://doi.org/10.1039/c3mb70362b

D'Amico AG, Maugeri G, Bucolo C, Saccone S, Federico C, Cavallaro S, D'Agata V (2017) NAP interferes with hypoxiainducible factors and VEGF expression in retina of diabetic rats. J Mol Neurosci 61:256-266. https://doi.org/10.1007/ s12031-016-0869-6
D'Amico AG, Maugeri G, Rasà D, Federico C, Saccone S, Lazzara F, Fidilio A, Drago F, Bucolo C, D'Agata V (2019) NAP modulates hyperglycemic-inflammatory event of diabetic retina by counteracting outer blood retinal barrier damage. J Cell Physiol 234(4):5230-5240. https://doi.org/10.1002/jcp.27331

D’Amico AG, Maugeri G, Rasà DM, La Cognata V, Saccone S, Federico C, Cavallaro S, D'Agata V (2018) NAP counteracts hyperglycemia/hypoxia induced retinal pigment epithelial barrier breakdown through modulation of HIFs and VEGF expression. J Cell Physiol 233(2):1120-1128. https://doi.org/10.1002/jcp.25971

D'Amico AG, Maugeri G, Reitano R, Bucolo C, Saccone S, Drago F, D'Agata V (2015) PACAP modulates expression of hypoxiainducible factors in streptozotocin-induced diabetic rat retina. J Mol Neurosci 57(4):501-509. https://doi.org/10.1007/ s12031-015-0621-7

D’Agata V, Cavallaro S (1998) Functional and molecular expression of PACAP/VIP receptors in the rat retina. Mol Brain Res 54:161164. https://doi.org/10.1016/s0169-328x(97)00335-5

D’Amico AG, Maugeri G, Rasà DM, Bucolo C, Saccone S, Federico C, Cavallaro S, D'Agata V (2017) Modulation of IL-1 $\beta$ and VEGF expression in rat diabetic retinopathy after PACAP administration. Peptides 97:64-69. https://doi.org/10.1016/j. peptides.2017.09.014 (PMID: 28964802)

Danyadi B, Szabadfi K, Reglodi D, Mihalik A, Danyadi T, Kovacs Z, Batai I, Tamas A, Kiss P, Toth G, Gabriel R (2014) PACAP application improves functional outcome of chronic retinal ischemic injury in rats-evidence from electroretinographic measurements. J Mol Neurosci 54:293-299. https://doi.org/10.1007/ s12031-014-0296-5

Divinski I, Mittelman L, Gozes I (2004) A femtomolar acting octapeptide interacts with tubulin and protects astrocytes against zinc intoxication. J Biol Chem 279:28531-28538. https://doi. org/10.1074/jbc.M403197200

Fabian E, Reglodi D, Horvath G, Opper B, Toth G, Fazakas C, Vegh AG, Wilhelm I, Krizbai IA (2019) Pituitary adenylate cyclase activating polypeptide acts against neovascularization in retinal pigment epithelial cells Ann N Y Acad Sci 1455(1):160-172. https://doi.org/10.1111/nyas.14189

Fabian E, Reglodi D, Mester L, Szabo A, Szabadfi K, Tamas A, Toth G, Kovacs K (2012) Effects of PACAP on intracellular signaling pathways in human retinal pigment epithelial cells exposed to oxidative stress. J Mol Neurosci 48(3):493-500. https://doi. org/10.1007/s12031-012-9812-7

Gábriel R (2013) Neuropeptides and diabetic retinopathy. Br J Clin Pharmacol 75(5):1189-1201. https://doi.org/10.1111/bcp.12003

Gábriel R, Pöstyéni E, Dénes V (2019) Neuroprotective potential of pituitary adenylate cyclase activating polypeptide in retinal degenerations of metabolic origin. Front Neurosci 13:1031. https://doi.org/10.3389/fnins.2019.01031

Gastinger MJ, Singh RS, Barber AJ (2006) Loss of cholinergic and dopaminergic amacrine cells in streptozotocin-diabetic rat and Ins2Akita-diabetic mouse retinas. Invest Ophthalmol Vis Sci 47:3143-3150. https://doi.org/10.1167/iovs.05-1376

Ghatei MA, Takahashi K, Suzuki Y, Gardiner J, Jones PM, Bloom SR (1993) Distribution, molecular characterization of pituitary adenylate cyclase-activating polypeptide and its precursor encoding messenger RNA in human and rat tissues. J Endocrinol 136:159166. https://doi.org/10.1677/joe.0.1360159

Girard BM, Campbell SE, Beca KI, Perkins M, Hsiang H, May V, Vizzard MA (2020) Intrabladder PAC1 Receptor Antagonist, PACAP(6-38), Reduces Urinary Bladder Frequency and Pelvic Sensitivity in Mice Exposed to Repeated Variate Stress (RVS). J Mol Neurosci. https://doi.org/10.1007/s12031-020-01649-X

Giunta S, Castorina A, Adorno A, Mazzone V, Carnazza ML, D’Agata V (2010) PACAP and VIP affect NF1 expression in rat malignant 
peripheral nerve sheath tumor (MPNST) cells. Neuropeptides 44(1):45-51. https://doi.org/10.1016/j.npep.2009.10.003

Giunta S, Castorina A, Bucolo C, Magro G, Drago F, D'Agata V (2012) Early changes in pituitary adenylate cyclase-activating peptide, vasoactive intestinal peptide and related receptors expression in retina of streptozotocin-induced diabetic rats. Peptides 37:32-39. https://doi.org/10.1016/j.peptides.2012.06.004

Gozes I (2020) The ADNP syndrome and CP201 (NAP) potential and hope. Neurol, Front. https://doi.org/10.3389/fneur.2020.608444

Gozes I, Alcalay R, Giladi E, Pinhasov A, Furman S, Brenneman DE (2002) NAP accelerates the performance of normal rats in the water maze. J Mol Neurosci 1-2:167-170. https://doi. org/10.1007/s12031-002-0028-0

Gozes I, Bassan M, Zamostiano R, Pinhasov A, Davidson A, Giladi E, Perl O, Glazner GW, Brenneman DE (1999) A novel signaling molecule for neuropeptide action: activity-dependent neuroprotective protein. Ann N Y Acad Sci 897:125-35. https://doi. org/10.1111/j.1749-6632.1999.tb07884.x

Gozes I, Divinski I, Piltzer I (2008) NAP and D-SAL: neuroprotection against the beta amyloid peptide (1-42) BMC Neurosci 9. Suppl 3(Suppl 3):S3. https://doi.org/10.1186/1471-2202-9-S3-S3

Gozes I, Divinsky I, Pilzer I, Fridkin M, Brenneman DE, Spier AD (2003) From vasoactive intestinal peptide (VIP) through activitydependent neuroprotective protein (ADNP) to NAP: a view of neuroprotection and cell division. J Mol Neurosci 20(3):315322. https://doi.org/10.1385/JMN:20:3:315

Gozes I, Ivashko-Pachima Y (2015) ADNP: in search for molecular mechanisms and innovative therapeutic strategies for frontotemporal degeneration. Front Aging Neurosci 7:205. https://doi. org/10.3389/fnagi.2015.00205

Gozes I, Ivashko-Pachima Y, Kapitansky O, Sayas CL, Iram T (2019) Single-cell analysis of cytoskeleton dynamics: From isoelectric focusing to live cell imaging and RNA-seq. J Neurosci Methods 323:119-124. https://doi.org/10.1016/j.jneumeth.2019.05.014

Gozes I, Ivashko-Pachima Y, Sayas CL (2018) ADNP, a microtubule interacting protein, provides neuroprotection through end binding proteins and Tau: an amplifier effect. Front Mol Neurosci 11:151. https://doi.org/10.3389/fnmol.2018.00151

Grigg I, Ivashko-Pachima Y, Hait TA, Korenková V, Touloumi O, Lagoudaki R, Van Dijck A, Marusic Z, Anicic M, Vukovic J, Kooy RF, Grigoriadis N, Gozes I (2020) Tauopathy in the young autistic brain: novel biomarker and therapeutic target. Transl Psychiatry 10(1):228. https://doi.org/10.1038/s41398-020-00904-4

Hannibal J (2002) Neurotransmitters of the retino-hypothalamic tract. Cell Tissue Res 309(1):73-88. https://doi.org/10.1007/ s00441-002-0574-3

Hannibal J, Ding JM, Chen D, Fahrenkrug J, Larsen PJ, Gillette MU, Mikkelsen JD (1997) Pituitary adenylate cyclase-activating peptide (PACAP) in the retinohypothalamic tract: a potential daytime regulator of the biological clock. J Neurosci 17(7):2637-2644. https://doi.org/10.1523/JNEUROSCI.17-07-02637

Harmar AJ, Arimura A, Gozes I, Journot L, Laburthe M, Pisegna JR, Rawlings SR, Robberecht P, Said SI, Sreedharan SP, Wank SA, Waschek JA (1998) International Union of Pharmacology. XVIII. Nomenclature of receptors for vasoactive intestinal peptide and pituitary adenylate cyclase-activating polypeptide. Pharmacol Rev 50(2):265-70

Harmar AJ, Fahrenkrug J, Gozes I, Laburthe M, May V, Pisegna JR, Vaudry D, Vaudry H, Waschek JA, Said SI (2012) Pharmacology and functions of receptors for vasoactive intestinal peptide and pituitary adenylate cyclase-activating polypeptide: IUPHAR review 1. Br J Pharmacol 166(1):4-17. https://doi.org/10. 1111/j.1476-5381.2012.01871.x

Holopigian K, Greenstein VC, Seiple W, Hood DC, Carr RE (1997) Evidence for photoreceptor changes in patients with diabetic retinopathy Invest Ophthalmol Vis Sci 38(11):2355-2365
Hosoya M, Onda H, Ogi K, Masuda Y, Miyamoto Y, Ohtaki T, Okazaki H, Arimura A and Fujino M (1993) Molecular cloning and functional expression of rat cDNAs encoding the receptor for pituitary adenylate cyclase-activating polypeptide (PACAP). Biochem Biophys Res Commun 15;194(1):133-43. https://doi. org/10.1006/bbrc.1993.1795

Idan-Feldman A, Schirer Y, Polyzoidou E, Touloumi O, Lagoudaki R, Grigoriadis NC, Gozes I (2011) Davunetide (NAP) as a preventative treatment for central nervous system complications in a diabetes rat model. Neurobiol Dis 44(3):327-339. https://doi. org/10.1016/j.nbd.2011.06.020

Ivashko-Pachima Y, Gozes I (2018) NAP protects against Tau hyperphosphorylation through GSK3. Curr Pharm Des 24(33):38683877. https://doi.org/10.2174/1381612824666181112105954

Ivashko-Pachima Y, Gozes I (2019) A novel microtubule-Tau association enhancer and neuroprotective drug candidate: AcSKIP. Front Cell Neurosci 13:435. https://doi.org/10.3389/ fncel.2019.00435

Ivashko-Pachima Y, Gozes I (2020) Deciphering the enigma: NAP (CP201) the active ADNP drug candidate enters cells by dynamin-associated endocytosis. J Mol Neurosci 70(7):993-998. https://doi.org/10.1007/s12031-020-01632-6

Ivashko-Pachima Y, Hadar A, Grigg I, Korenková V, Kapitansky O, Karmon G, Gershovits M, Sayas CL, Kooy RF, Attems J, Gurwitz D, Gozes I (2019) Discovery of autism/intellectual disability somatic mutations in Alzheimer's brains: mutated ADNP cytoskeletal impairments and repair as a case study. Mol Psychiatry. https://doi.org/10.1038/s41380-019-0563-5

Ivashko-Pachima Y, Sayas CL, Malishkevich A, Gozes I (2017) ADNP/ NAP dramatically increase microtubule end-binding proteinTau interaction: a novel avenue for protection against tauopathy. Mol Psychiatry 22(9):1335-1344. https://doi.org/10.1038/ mp.2016.255

Jehle T, Dimitriu C, Auer S, Knoth R, Vidal-Sanz M, Gozes I, Lagrèze WA (2008) The neuropeptide NAP provides neuroprotection against retinal ganglion cell damage after retinal ischemia and optic nerve crush. Graefes Arch Clin Exp Ophthalmol 246(9):1255-1263. https://doi.org/10.1007/s 00417-007-07467ErratuminGraefesArchClinExpOphthalmol.2008Sep;246(9):1355

Józsa R, Somogyvári-Vigh A, Reglödi D, Hollósy T, Arimura A (2001) Distribution and daily variations of PACAP in the chicken brain. Peptides 22(9):1371-1377. https://doi.org/10.1016/ s0196-9781(01)00477-6

Kapitansky O, Sragovich S, Jaljuli I, Hadar A, Giladi E, Gozes I (2020) Age and sex-dependent ADNP regulation of muscle gene expression is correlated with motor behavior: possible feedback mechanism with PACAP. Int J Mol Sci 21(18):6715. https://doi. org/10.3390/ijms21186715

Kovacs AK, Atlasz T, Werling D, Szabo E, Reglodi D, Toth GK (2020) Stability test of PACAP in eye drops. J Mol Neurosci. https://doi. org/10.1007/s12031-020-01532-9

Kovács-Valasek A, Szabadfi K, Dénes V, Szalontai B, Tamás A, Kiss P, Szabó A, Setalo G Jr, Reglődi D, Gábriel R (2017) Accelerated retinal aging in PACAP knock-out mice. Neuroscience 348:1-10. https://doi.org/10.1016/j.neuroscience.2017.02.003

Kvarik T, Mammel B, Reglodi D, Kovacs K, Werling D, Bede B, Vaczy A, Fabian E, Toth G, Kiss P, Tamas A, Ertl T, Gyarmati J, Atlasz T (2016) PACAP is protective in a rat model of retinopathy of prematurity. J Mol Neurosci 60(2):179-185. https:// doi.org/10.1007/s12031-016-0797-5

Laburthe M, Couvineau A, Marie JC (2002) VPAC receptors for VIP and PACAP. Recept Channels 8(3-4):137-153

Lagrèze WA, Pielen A, Steingart R, Schlunck G, Hofmann H, Gozes I, Kirsch M (2005) The peptides ADNF-9 and NAP increase survival and neurite outgrowth of rat retinal ganglion cells 
in vitro. Invest Ophthalmol Vis Sci 46(3):933-938. https://doi. org/10.1167/iovs.04-0766

Lakk M, Denes V, Gabriel R (2015) Pituitary adenylate cyclase-activating polypeptide receptors signal via phospholipase $\mathrm{C}$ pathway to block apoptosis in newborn rat retinaneurochem Res 40(7):14021409. https://doi.org/10.1007/s11064-015-1607-0

Lakk M, Szabo B, Volgyi B, Gabriel R, Denes V (2012) Development-related splicing regulates pituitary adenylate cyclaseactivating polypeptide (PACAP) receptors in the retina. Invest Ophthalmol Vis Sci 53(12):7825-7832. https://doi.org/10.1167/ iovs.12-10417

Leker RR, Teichner A, Grigoriadis N, Ovadia H, Brenneman DE, Fridkin M, Giladi E, Romano J, Gozes I (2002) NAP, a femtomolaracting peptide, protects the brain against ischemic injury by reducing apoptotic death. Stroke 33:1085-1092

Li M, David C, Kikuta T, Somogyvari-Vig A, Arimura A (2005) Signaling cascades involved in neuroprotection by subpicomolar pituitary adenylate cyclase-activating polypeptide 38 . J Mol Neurosci 27(1):91-105. https://doi.org/10.1385/JMN:27:1:091

Lutz EM, Sheward WJ, West KM, Morrow JA, Fink G, Harmar AJ (1993) The VIP receptor: molecular characterisation of a cDNA encoding a novel receptor for vasoactive intestinal peptide. FEBS Lett 334(1):3-8. https://doi.org/10.1016/0014-5793(93)81668-p

Martínez-Rojas VA, Jiménez-Garduño AM, Michelatti D, Tosatto L, Marchioretto M, Arosio D, Basso M, Pennuto M, Musio C (2020) ClC-2-like chloride current alterations in a cell model of spinal and bulbar muscular atrophy, a polyglutamine disease. J Mol Neurosci. https://doi.org/10.1007/s12031-020-01687-5

Maugeri G, D’Amico AG, Bucolo C, D’Agata V (2019b) Protective effect of PACAP-38 on retinal pigmented epithelium in an in vitro and in vivo model of diabetic retinopathy through EGFR-dependent mechanism. Peptides 119:170108. https://doi. org/10.1016/j.peptides.2019.170108

Maugeri G, D’Amico AG, Castrogiovanni P, Saccone S, Federico C, Reibaldi M, Russo A, Bonfiglio V, Avitabile T, Longo A, D'Agata V (2019) PACAP through EGFR transactivation preserves human corneal endothelial integrity. J Cell Biochem 120(6):10097-10105. https://doi.org/10.1002/jcb.28293

Maugeri G, D’Amico AG, Gagliano C, Saccone S, Federico C, Cavallaro S, D'Agata V (2017) VIP family members prevent outer blood retinal barrier damage in a model of diabetic macular edema. J Cell Physiol 232(5):1079-1085. https://doi. org/10.1002/jcp.25510

Maugeri G, D'Amico AG, Saccone S, Federico C, Cavallaro S, D'Agata V (2017) PACAP and VIP inhibit HIF- $1 \alpha$-mediated VEGF expression in a model of diabetic macular edema. J Cell Physiol 232(5):1209-1215. https://doi.org/10.1002/jcp.25616

Maugeri G, Longo A, D'Amico AG, Rasà DM, Reibaldi M, Russo A, Bonfiglio V, Avitabile T, D’Agata V (2018) Trophic effect of PACAP on human corneal endothelium. Peptides 99:20-26. https://doi.org/10.1016/j.peptides.2017.11.003

Mester L, Kovacs K, Racz B, Solti I, Atlasz T, Szabadfi K, Tamas A, Reglodi D (2011) Pituitary adenylate cyclase-activating polypeptide is protective against oxidative stress in human retinal pigment epithelial cells. J Mol Neurosci 43(1):35-43. https:// doi.org/10.1007/s12031-010-9427-9

Miyata A, Arimura A, Dahl RR, Minamino N, Uehara A, Jiang L, Culler MD, Coy DH (1989) Isolation of a novel 38 residuehypothalamic polypeptide which stimulates adenylate cyclase in pituitary cells. Biochem Biophys Res Commun 164:567-574

Miyata A, Jiang L, Dahl RD, Kitada C, Kubo K, Fujino M, Minamino $\mathrm{N}$, Arimura A (1990) Isolation of a neuropeptide corresponding to the N-terminal 27 residues of the pituitary adenylate cyclase activating polypeptide with 38 residues (PACAP38). Biochem Biophys Res Commun 170:643-648
Moody TW, Lee L, Jensen RT (2020) The G protein-coupled receptor PAC1 regulates transactivation of the receptor tyrosine kinase HER3. J Mol Neurosci. https://doi.org/10.1007/s12031-02001711-8

Morrow JA, Lutz EM, West KM, Fink G and Harmar AJ (1993) Molecular cloning and expression of a cDNA encoding a receptor for pituitary adenylate cyclaseactivating polypeptide (PACAP). FEBS Lett 329:99-105

Nakamachi T, Farkas J, Watanabe J, Ohtaki H, Dohi K, Arata S, Shioda S (2011) Role of PACAP in neural stem/progenitor cell and astrocyte-from neural development to neural repair. Curr Pharm 17(10):973-984. https://doi.org/10.2174/138161211795589346

Nakamachi T, Li M, Shioda S, Arimura A (2006) Signaling involved in pituitary adenylate cyclase-activating polypeptide-stimulated ADNP expression. Peptides 27(7):1859-1864. https://doi. org/10.1016/j.peptides.2006.01.007

Nakamachi T, Matkovits A, Seki T, Shioda S (2012) Front Endocrinol (Lausanne). Distribution and protective function of pituitary adenylate cyclase-activating polypeptide in the retina $3: 145$. https:// doi.org/10.3389/fendo.2012.00145

Nakamachi T, Ohtaki H, Seki T, Yofu S, Kagami N, Hashimoto H, Shintani N, Baba A, Mark L, Lanekoff I, Kiss P, Farkas J, Reglodi D, Shioda S (2016) PACAP suppresses dry eye signs by stimulating tear secretion. Nat Commun 7:12034. https://doi. org/10.1038/ncomms12034

Nakamachi T, Ohtaki H, Yofu S, Dohi K, Watanabe J, Hayashi D, Matsuno R, Nonaka N, Itabashi K, Shioda S (2008) Pituitary adenylate cyclase-activating polypeptide (PACAP) type 1 receptor (PAC1R) co-localizes with activity-dependent neuroprotective protein (ADNP) in the mouse brains. Regul Pept 145(1-3):8895. https://doi.org/10.1016/j.regpep.2007.09.025

Nakatani M, Seki T, Shinohara Y, Taki C, Nishimura S, Takaki A, Shioda S (2006) Pituitary adenylate cyclase-activating peptide (PACAP) stimulates production of interleukin-6 in rat Müller cells. Peptides 27:1871-1876. https://doi.org/10.1016/j. peptides.2005.12.011

Njaine B, Martins RA, Santiago MF, Linden R, Silveira MS (2010) Pituitary adenylyl cyclase-activating polypeptide controls the proliferation of retinal progenitor cells through downregulation of cyclin D1. Eur J Neurosci 32(3):311-321. https://doi.org/10. $1111 / \mathrm{j} .1460-9568.2010 .07286 . x$

Ohtaki H, Nakamachi T, Dohi K, Shioda S (2008) Role of PACAP in ischemic neural death. J Mol Neurosci 36(1-3):16-25. https://doi. org/10.1007/s12031-008-9077-3

Onali P, Olianas MC (1994) PACAP is a potent and highly effective stimulator of adenylyl cyclase activity in the retinas of different mammalian species. Brain Res 641(1):132-134. https://doi. org/10.1016/0006-8993(94)91825-2

Oz S, Ivashko-Pachima Y, Gozes I (2012) The ADNP derived peptide, NAP modulates the tubulin pool: implication for neurotrophic and neuroprotective activities. PLoS ONE 7(12):e51458. https://doi.org/10.1371/journal.pone.0051458

Oz S, Kapitansky O, Ivashco-Pachima Y, Malishkevich A, Giladi E, Skalka N, Rosin-Arbesfeld R, Mittelman L, Segev O, Hirsch JA, Gozes I (2014) The NAP motif of activity-dependent neuroprotective protein (ADNP) regulates dendritic spines through microtubule end binding proteins. Mol Psychiatry 19(10):1115-24. https://doi.org/10.1038/mp.2014.97

Pilzer I, Gozes I (2006) VIP provides cellular protection through a specific splice variant of the PACAP receptor: a new neuroprotection target. Peptides 27(11):2867-2876. https://doi.org/10.1016/j. peptides.2006.06.007

Pinhasov A, Mandel S, Torchinsky A, Giladi E, Pittel Z, Goldsweig AM, Servoss SJ, Brenneman DE, Gozes I (2003) Activitydependent neuroprotective protein: a novel gene essential 
for brain formation. Brain Res Dev Brain Res 144(1):83-90. https://doi.org/10.1016/s0165-3806(03)00162-7

Pisegna JR and Wank SA (1993) Molecular cloning and functional expression of the pituitary adenylate cyclase-activating polypeptide type I receptor. Proc Natl Acad Sci USA 1;90(13):63459. https://doi.org/10.1073/pnas.90.13.6345

Puro DG (2002) Diabetes-induced dysfunction of retinal Muller cells. Trans Am Ophthalmol 100:339-352

Racz B, Gallyas F Jr, Kiss P, Tamas A, Lubics A, Lengvari I, Roth E, Toth G, Hegyi O, Verzal Z, Fabricsek C, Reglodi D (2007) Effects of pituitary adenylate cyclase activating polypeptide (PACAP) on the PKA-Bad-14-3-3 signaling pathway in glutamate-induced retinal injury in neonatal rats. Neurotox Res 12(2):95-104. https://doi.org/10.1007/BF03033918

Rácz B, Gallyas F Jr, Kiss P, Tóth G, Hegyi O, Gasz B, Borsiczky B, Ferencz A, Roth E, Tamás A, Lengvári I, Lubics A, Reglodi D (2006) The neuroprotective effects of PACAP in monosodium glutamate-induced retinal lesion involves inhibition of proapoptotic signaling pathways. Regul Pept 137(1-2):20-26. https://doi. org/10.1016/j.regpep.2006.02.009

Rácz B, Tamás A, Kiss P, Tóth G, Gasz B, Borsiczky B, Ferencz A, Gallyas F Jr, Roth E, Reglodi D (2006) Involvement of ERK and CREB signaling pathways in the protective effect of PACAP in monosodium glutamate-induced retinal lesion. Ann N Y Acad Sci 1070:507-511. https://doi.org/10.1196/annals.1317.070

Reglodi D, Somogyvari-Vigh A, Vígh J, Li M, Lengvári I, Arimura A (2001) Pituitary adenylate cyclase activating polypeptide is highly abundant in the nervous system of the anoxia-tolerant turtle. Pseudemys scripta elegans Peptides 22(6):873-878. https://doi.org/10.1016/s0196-9781(01)00412-0

Scuderi S, D'Amico AG, Castorina A, Federico C, Marrazzo G, Drago F, Bucolo C, D'Agata V (2014) Davunetide (NAP) protects the retina against early diabetic injury by reducing apoptotic death. J Mol Neurosci 54(3):395-404. https://doi.org/10.1007/ s12031-014-0244-4

Scuderi S, D’Amico AG, Castorina A, Imbesi R, Carnazza ML, D'Agata V (2013) Ameliorative effect of PACAP and VIP against increased permeability in a model of outer blood retinal barrier dysfunction. Peptides 39:119-124. https://doi.org/10.1016/j. peptides.2012.11.015

Scuderi S, D’Amico AG, Federico C, Saccone S, Magro G, Bucolo C, Drago F, D'Agata V (2015) Different Retinal Expression Patterns of IL-1 $\alpha$, IL-1 $\beta$, and Their Receptors in a Rat Model of Type 1 STZ-Induced Diabetes. J Mol Neurosci 56(2):431-439. https:// doi.org/10.1007/s12031-015-0505-x

Segre GV, Goldring SR (1993) Receptors for secretin, calcitonin, parathyroid hormone PTH)/PTH-related peptide, glucagon-like peptide 1, growth hormonereleasing hormone, and glucagon belong to a newly discovered G-protein-linked receptor family. Trends Endocrinol Metab 4(10):309-314. https://doi.org/10.1016/10432760(93)90071-1

Seki T, Itoh H, Nakamachi T, Endo K, Wada Y, Nakamura K, Shioda S (2011) Suppression of rat retinal ganglion cell death by PACAP following transient ischemia induced by high intraocular pressure. J Mol Neurosci 43(1):30-4. https://doi.org/10.1007/ s12031-010-9410-5

Seki T, Izumi S, Shioda S, Zhou CJ, Arimura A, Koide R (2000) Gene expression for PACAP receptor mRNA in the rat retina by in situ hybridization and in situ RT-PCR. Ann NY Acad Sci 921:366369. https://doi.org/10.1111/j.1749-6632.2000.tb06995.x

Seki T, Shioda S, Ogino D, Nakai Y, Arimura A, Koide R (1997) Distribution and ultrastructural localization of a receptor for pituitary adenylate cyclase activating polypeptide and its mRNA in the rat retina. Neurosci Lett 238:127-130. https://doi. org/10.1016/s0304-3940(97)00869-0
Seki T, Shioda S, Izumi S, A. Arimura A, Koide R, (2000) Electron microscopic observation of pituitary adenylate cyclase activating polypeptide (PACAP)-containing neurons in the rat retina. Peptides 21(1):109-113. https://doi.org/10.1016/ s0196-9781(99)00180-1

Seki T, Shioda S, Nakai Y, Arimura A, Koide R (1998) Distribution and ultrastructural localization of pituitary adenylate cyclase-activating polypeptide (PACAP) and its receptor in the rat retina. Ann N Y Acad Sci 865:408-411. https://doi. org/10.1111/j.1749-6632.1998.tb11205.x

Shioda S, Ohtaki H, Nakamachi T, Dohi K, Watanabe J, Nakajo S, Arata S, Kitamura S, Okuda H, Takenoya F, Kitamura Y (2006) Pleiotropic functions of PACAP in the CNS: neuroprotection and neurodevelopment. Ann. N.Y. Acad Sci 1070:550-560. https:// doi.org/10.1196/annals.1317.080

Silveira MS, Costa MR, Bozza M, Linden R (2002) Pituitary adenylyl cyclase-activating polypeptide prevents induced cell death in retinal tissue through activation of cyclic AMP-dependent protein kinase. J Biol Chem 277:16075-16080. https://doi.org/10.1074/ jbc.M110106200

Simó R, Villarroel M, Corraliza L, Hernández C, Garcia - Ramírez M (2010) The retinal pigment epithelium: Something more than a constituent of the blood - retinal - barrier - implications for the pathogenesis of diabetic retinopathy. Journal of Biomedicine and Biotechnology (2010) 190724-15. J Biomed Biotechnol 2010:190724. https://doi.org/10.1155/2010/190724

Solymar M, Ivic I, Balasko M, Fulop BD, Toth G, Tamas A, Reman G, Koller A, Reglodi D (2018) Pituitary adenylate cyclase-activating polypeptide ameliorates vascular dysfunction induced by hyperglycaemia. Diab Vasc Dis Res 15(4):277-285. https://doi. org/10.1177/1479164118757922

Somogyvari-Vigh A, Reglodi D (2004) Pituitary adenylate cyclase activating polypeptide: a potential neuroprotective peptide. Curr Pharm Des 10:2861-2889. https://doi.org/10.2174/ 1381612043383548

Sragovich S, Ziv Y, Vaisvaser S, Shomron N, Hendler T, Gozes I (2019) The autism-mutated ADNP plays a key role in stress response. Transl Psychiatry 9(1):235. https://doi.org/10.1038/ s41398-019-0569-4

Svoboda M, Tastenoy M, Ciccarelli E, StieÂ venart M and Christophe J, (1993) Cloning of a splice variant of the pituitary adenylate cyclase-activating polypeptide (PACAP) type I receptor. Biochem Biophys Res Commun 195(2):881-888. https://doi. org/10.1006/bbrc.1993.2127

Szabadfi K, Atlasz T, Kiss P, Reglodi D, Szabo A, Kovacs K, Szalontai B, Setalo GyJr, Banki E, Csanaky K, Tamas A, Gabriel R (2012) Protective effects of the neuropeptide PACAP in diabetic retinopathy. Cell Tissue Res 348(1):37-46. https://doi.org/10.1007/ s00441-012-1349-0

Szabadfi K, Reglodi D, Szabo A, Szalontai B, Valasek A, Setalo G Jr, Kiss P, Tamas A, Wilhelm M, Gabriel R (2016) Pituitary adenylate cyclase activating polypeptide, a potential therapeutic agent for diabetic retinopathy in rats: focus on the vertical information processing pathway. Neurotox Res 29:432-446. https:// doi.org/10.1007/s12640-015-9593-1

Szabadfi K, Szabo A, Kiss P, Reglodi D, Setalo GJr, Kovacs K, Tamas A, Toth G, Gabriel R, (2014) PACAP promotes neuron survival in early experimental diabetic retinopathy. Neurochem Int 64:8491. https://doi.org/10.1016/j.neuint.2013.11.005

Szabo A, Danyadi B, Bognar E, Szabadfi K, Fabian E, Kiss P, Mester L, Manavalan S, Atlasz T, Gabriel R, Toth G, Tamas A, Reglodi D, Kovacs K (2012) Effect of PACAP on MAP kinases, Akt and cytokine expressions in rat retinal hypoperfusion. Neurosci Lett 523(2):93-98. https://doi.org/10.1016/j.neulet.2012.06.044

Toth D, Szabo E, Tamas A, Juhasz T, Horvath G, Fabian E, Opper B, Szabo D, Maugeri G, D’Amico AG, D’Agata V, Vicena 
V, Reglodi D (2020) Protective effects of PACAP in peripheral organs. Front Endocrinol Lausanne 11:377. https://doi. org/10.3389/fendo.2020.00377

Vaczy A, Reglodi D, Somoskeoy T, Kovacs K, Lokos E, Szabo E, Tamas A, Atlasz T (2016) The protective role of PAC1- receptor agonist maxadilan in BCCAO-induced retinal degeneration. J Mol Neurosci 60(2):186-194. https://doi.org/10.1007/ s12031-016-0818-4

Varga B, Szabadfi K, Kiss P, Fabian E, Tamas A, Griecs M, Gabriel R, Reglodi D, Kemeny-Beke A, Pamer Z, Biro Z, TosakiA AT, Juhasz B (2011) PACAP improves functional outcome in excitotoxic retinal lesion: an electroretinographic study. J Mol Neurosci 43(1):44-50. https://doi.org/10.1007/s12031-010-9406-1

Vaudry D, Falluel-Morel A, Basille M, Pamantung TF, Fontaine M, Fournier A, Vaudry H, Gonzalez BJ (2003) Pituitary adenylate cyclase-activating polypeptide prevents $\mathrm{C} 2$-ceramide-induced apoptosis of cerebellar granule cells. J Neurosci Res 72(3):303316. https://doi.org/10.1002/jnr.10530

Vaudry D, Falluel-Morel A, Bourgault S, Basille M, Burel D, Wurtz O, Fournier A, Chow BK, Hashimoto H, Galas L, Vaudry H (2009) Pituitary adenylate cyclase activating polypeptide and its receptors: 20 years after the discovery. Pharmacol Rev 61:283-357. https://doi.org/10.1124/pr.109.001370

Wada Y, Nakamachi T, Endo K, Seki T, Ohtaki H, Tsuchikawa D, Hori M, Tsuchida M, Yoshikawa A, Matkovits A, Kagami N, Imai N, Fujisaka S, Usui I, Tobe K, Koide R, Takahashi H, Shioda S (2013) PACAP attenuates NMDA-induced retinal damage in association with modulation of the microglia/macrophage status into an acquired deactivation subtype. J Mol Neurosci 51(2):493502. https://doi.org/10.1007/s12031-013-0017-5

Wang ZY, Alm P, Hakanson R (1995) Distribution and effects of pituitary adenylate cyclase-activating peptide in the rabbit eye. Neuroscience 69(1):297-308. https://doi.org/10.1016/03064522(95)00258-k

Waschek JA (2002) Multiple actions of pituitary adenylyl cyclase activating peptide in nervous system development and regeneration. Dev Neurosci 24(1):14-23. https://doi.org/10.1159/000064942

Werling D, Banks WA, Salameh TS, Kvarik T, Kovacs LA, Vaczy A, Szabo E, Mayer F, Varga R, Tamas A, Toth G, Biro Z, Atlasz T, Reglodi D (2017) Passage through the ocular barriers and beneficial effects in retinal ischemia of topical application of PACAP138 in rodents. Int J Mol Sci 18(3):675. https://doi.org/10.3390/ ijms 18030675

Werling D, Reglodi D, Banks WA, Salameh TS, Kovacs K, Kvarik T, Vaczy A, Kovacs L, Mayer F, Danyadi B, Lokos E, Tamas A, Toth G, Zs B, Tamas A, Atlasz T (2016) Ocular delivery of PACAP1-27 protects the retina from ischemic damage in rodents. Invest Ophthalmol Vis Sci 57(15):6683-6691. https:// doi.org/10.1167/iovs.16-20630
Yau JW, Rogers SL, Kawasaki R, Lamoureux EL, Kowalski JW, Bek T, Chen SJ, Dekker JM, Fletcher A, Grauslund J, Haffner S, Hamman RF, Ikram MK, Kayama T, Klein BE, Klein R, Krishnaiah S, Mayurasakorn K, O'Hare JP, Orchard TJ, Porta M, Rema M, Roy MS, Sharma T, Shaw J, Taylor H, Tielsch JM, Varma R, Wang JJ, Wang N, West S, Xu L, Yasuda M, Zhang X, Mitchell P, Wong TY, Meta-Analysis for Eye Disease (META-EYE) Study Group (2012) Global prevalence and major risk factors of diabetic retinopathy. Diabetes Care 35:556-564. https://doi. org/10.2337/dc11-1909

Ye D, Shi Y, Xu Y, Huang J (2019) PACAP attenuates optic nerve crush-induced retinal ganglion cell apoptosis via activation of the CREB-Bcl-2 pathway. J Mol Neurosci 68(3):475-484. https://doi.org/10.1007/s12031-019-01309-9

Zaltzman R, Alexandrovich A, Trembovler V, Shohami E, Gozes I (2005) The influence of the peptide NAP on Mac-1-deficient mice following closed head injury. Peptides 26:1520-1527. https://doi.org/10.1016/j.peptides.2005.03.014

Zamostiano R, Pinhasov A, Gelber E, Steingart RA, Seroussi E, Giladi E, Bassan M, Wollman Y, Eyre HJ, Mulley JC, Brenneman DE, Gozes I (2001) Cloning and characterization of the human activity-dependent neuroprotective protein. J Biol Chem 276(1):70814. https://doi.org/10.1074/jbc.M007416200.

Zemlyak I, Manley N, Sapolsky R, Gozes I (2007) NAP protects hippocampal neurons against multiple toxins. Peptides 28(10):20042008. https://doi.org/10.1016/j.peptides.2007.08.004

Zeng HY, Green WR, Tso MO (2008) Microglial activation in human diabetic retinopathy. Arch Ophthalmol 126:227-232. https://doi. org/10.1001/archophthalmol.2007.65

Zeng XX, Ng YK, Ling EA (2000) Neuronal and microglial response in the retina of streptozotocin-induced diabetic rats. Vis Neurosci 17:463-471. https://doi.org/10.1017/s0952523800173122

Zhang XY, Hayasaka S, Chi Z-L, Cui H-S, Hayasaka Y (2005) Effect of pituitary adenylate cyclase activating polypeptide (PACAP) on IL-6, and MCP-1 expression in human retinal pigment epithelial cell line. Curr Eye Res 30:1105-1111. https://doi. org/10.1080/02713680500421444

Zheng Y, Zeng H, She H, Liu H, Sun N (2010) Expression of peptide NAP in rat retinal Müller cells prevents hypoxia-induced retinal injuries and promotes retinal neurons growth. Biomed Pharmacother 64(6):417-423. https://doi.org/10.1016/j. biopha.2010.01.016

Zusev M, Gozes I (2004) Differential regulation of activity-dependent neuroprotective protein in rat astrocytes by VIP and PACAP Regul Pept 123(1-3):33-41. https://doi.org/10.1016/j. regpep.2004.05.021

Publisher's Note Springer Nature remains neutral with regard to jurisdictional claims in published maps and institutional affiliations. 